\title{
Commodity lending in the region agriculture
}

\author{
Kirill Zhichkin ${ }^{1, *}$, Vladimir Nosov ${ }^{2}$, and Lyudmila Zhichkina ${ }^{1}$, Eduard Badanin ${ }^{3}$, Liudmila \\ Voloshchuk $^{4}$, and Olga Kotar ${ }^{4}$ \\ ${ }^{1}$ Samara State Agrarian University, 2 Uchebnaja str., Kinel, 446442, Russia \\ ${ }^{2}$ K.G. Razumovsky Moscow State University of technologies and management, 73 Zemlyanoy val, \\ Moscow, 109004, Russia \\ ${ }^{3}$ Kuban State Technological University, 2 Moskovskaya str., Krasnodar, 350072, Russia \\ ${ }^{4}$ Saratov State Vavilov Agrarian University, 1 Teatralnaya square, Saratov, 410012, Russia
}

\begin{abstract}
The article examined the existing experience of using commodity lending. The work purpose is to identify the features of commodity lending as an element of the state support system for agricultural production. Within the framework of this goal, the following tasks were solved: - theoretical aspects of commodity lending were studied; - the american experience of using commodity lending within the framework of the Commodity Credit Corporation was reviewed; proposed commodity lending classification in agriculture; - the Samara region experience was studied and promising directions for the development of commodity lending in the region were proposed. In the Samara region, the state support operator in the form of commodity lending is the SUE "Veles", which has been operating since 2010. Thanks to the activities of the SUE "Veles" from 2011 to 2016 it was possible to change the livestock reduction negative trend in the region and ensure its growth.
\end{abstract}

\section{Introduction}

Agricultural production refers to the sectors of material production with a long cycle. Depending on the industry affiliation (crop production, livestock breeding), the enterprise is forced to link its material and technical resources in the form of work in progress for a long time, reducing its liquidity and worsening production and financial performance. At the same time, relatively low profitability (in relation to other sectors - industry, trade, services) does not always make it possible to compensate for the losses incurred and to compensate for the losses incurred due to the appearance of a long time lag. Therefore, there is a need to use tools to at least partially compensate for this effect. One of such mechanisms may be commodity lending to agricultural producers [1-4].

In general, a commodity loan is "a type of loan obligation arising when a lender provides the borrower with things determined by generic characteristics, in a certain name, quantity and assortment on the basis of payment, repayment, urgency, and security" [5]. In

\footnotetext{
* Corresponding author: zskirill@mail.ru
} 
this form, it is a form of commercial loan with individual features (form of provision of resources) [6].

In modern conditions, the types of commodity lending are diverse in nature, as shown in Fig. 1. Due to this diversity, commodity lending can now be used as an active element of the state support system for agriculture. Most economists believed that the goal of "... a commodity loan is not the goods exchange, but the beneficial effect creation." [7-10]

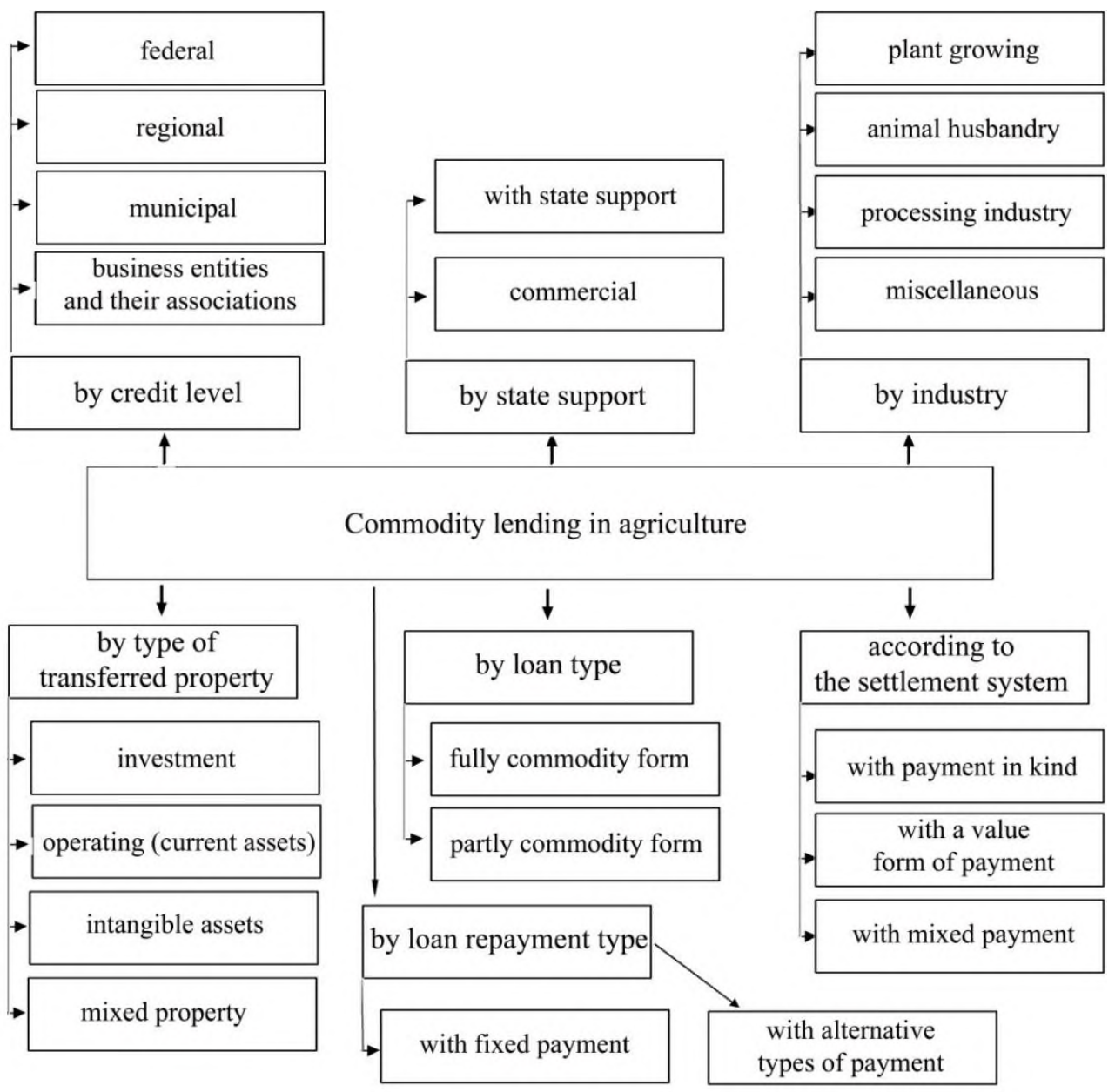

Fig. 1. The commodity lending classification in agriculture.

The most fully and varied possibilities of commodity lending are used in the US agricultural sector state regulation system [11-22]. There, in 1948, the Commodity Credit Corporation (CCC) was established, the main function of which was commodity lending to agricultural producers [23]. In addition to traditional commodity loans, CCC give shortterm loans (for financing working capital) against a future crop. When repaying such a loan, the farmer has two options: 1) to repay the loan with interest accrued in cash and independently manage the grown produce; 2) do not pay the loan and leave your harvest in the CCC ownership. Two points must be distinguished: 1) the loan rate is less than the rate on short-term loans in commercial banks; 2) the price at which ownership passes to CCC (collateral price) is determined in advance (by the Federal Law) and indexed annually. Thus, it is the lowest level of the domestic market price in the USA and ensures price 
stability for the main groups of agricultural products (grain, meat, dairy products) within the country [24].

In general, commodity lending in the United States performs the following functions:

- providing working capital for the production process;

- formation of state intervention funds;

- seasonal supply and demand stabilization for agricultural products;

- priority areas stimulation for the agribusiness development;

- foreign economic activity stimulation for agricultural, engineering and other enterprises; 26].

- inflation targeting (through collateralized prices for agricultural products), etc. [25-

\section{Methods and materials}

The work purpose is to identify the features of commodity lending as a state support system element for agricultural production. Within the framework of this goal, the following tasks were solved: - commodity lending theoretical aspects were studied; - the american experience of using commodity lending within the Commodity Credit Corporation framework was reviewed; - proposed commodity lending classification in agriculture; - the Samara region experience was studied and promising directions for the commodity lending development in the region were proposed.

The study object is economic relations between agricultural producers and public authorities in the commodity lending, carried out in the state support framework. In the study course, the abstract logical method, situational and system analysis, economic and statistical methods, and the method of expert evaluations were used.

\section{Results and discussion}

In the Samara region the commodity lending use in agriculture is so far limited to two main areas. The first is a commercial loan at the economic entities level (provision of seeds, pesticides, fertilizers, etc. at the season beginning and settlement at the end with money or finished products). The second is commodity lending with state support through the State Unitary Enterprise "Veles". In this area, the state (represented by the SUE) provides pedigree or commodity livestock to agricultural enterprises in the region. At the loan term end, the organization must return as many head of cattle. Moreover, the annual payment is $5 \%$ of original head the book value. At the same time, the strategic goals is achieved - the preservation and increase in the livestock number in the region. The commodity lending similar type is used in other regions [27]. 
Table 1. Livestock on all categories farms of the Samara region on January 1, thousand head.

\begin{tabular}{|c|c|c|c|c|c|c|c|c|c|c|}
\hline Years & 2000 & 2010 & 2011 & 2012 & 2013 & 2014 & 2015 & 2016 & 2017 & 2018 \\
\hline$\underset{\text { 苞 }}{\stackrel{0}{E}}$ & 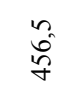 & $\vec{\Omega}$ & ते & $\underset{\sim}{\stackrel{\sim}{v}}$ & $\hat{\tilde{a}}$ & 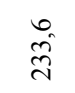 & $\begin{array}{r}\tilde{n} \\
\stackrel{f}{\sim}\end{array}$ & $\begin{array}{l}\hat{\delta} \\
\hat{\sim}\end{array}$ & $\begin{array}{l}\infty \\
\tilde{n} \\
\dot{n}\end{array}$ & $\begin{array}{l}0 \\
\infty \\
\text { ते }\end{array}$ \\
\hline 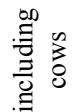 & $\stackrel{\overrightarrow{\hat{\sigma}}}{\overrightarrow{\hat{v}}}$ & $\begin{array}{l}n \\
\tilde{8}\end{array}$ & on & $\begin{array}{l}i \\
\tilde{o}\end{array}$ & $\begin{array}{l}0 \\
i \\
0\end{array}$ & & $\stackrel{\text { }}{\Xi}$ & $\underset{\Xi}{\Xi}$ & on & $\stackrel{\hat{\sigma}}{\hat{0}}$ \\
\hline 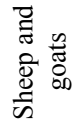 & $\begin{array}{l}n \\
\tilde{\Xi}\end{array}$ & $\frac{\pi}{\sigma}$ & $\begin{array}{l}\circ \\
\text { है }\end{array}$ & $\stackrel{\widetilde{\Xi}}{\Xi}$ & $\overrightarrow{0}$ & 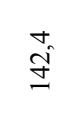 & 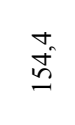 & $\begin{array}{l}0 \\
\tilde{n}\end{array}$ & $\tilde{\tilde{g}}$ & $\begin{array}{l}3 \\
\tilde{I}\end{array}$ \\
\hline
\end{tabular}

The commodity lending system has proven to be quite effective. Since 2011, in the region, despite the negative market situation, it has been possible to stabilize the cattle number. Until 2016, the growth was 70\% compared with 2010 data for small cattle and $22.3 \%$ for cattle (Table 1). During this time, within the framework of the Samara region program implementation "Development of the Samara region agriculture and markets regulation for agricultural products, raw materials and food" and livestock development measures as a commodity loan to the region farms, 14214 head cattle were purchased and transferred to SUE «Veles», including 1808 pedigree animals, and 7491 hesd small cattle, including - 3245 pedigree head.

Of the cattle total number, 8305 animals were dairy (58\%), including mainly blackmotley breed (7413 head), red-motley breed (341 head), Kholmogorsky breed (200 head), brown Schwyz breed (121 head), Simmental breed (201 head) and Bestuzhev breed (29 head).

5909 head beef cattle were purchased and transferred under commodity loan agreements to agricultural producers in the Samara region, including Simmental breed (2290 animals), Kazakh White-headed breed (2648 animals), Hereford breed (549 animals), AberdeenAngus breed (308 head) and Kalmyk breed (114 head).

Cattle were purchased mainly outside the region: in the Republic of Bashkiria, the Republic of Mordovia, the Republic of Mari-El, Saratov, Sverdlovsk, Tver, Penza, Nizhny Novgorod, Kirov regions, as well as in the Perm Territory.

Of the cattle purchased total number 8217 heifers (58\%), 4444 calves, 1522 cows and 31 bulls were bought.

Small cattle (sheep) were purchased in the Saratov and Astrakhan regions. The breed composition is represented mainly by the Edilbaevskaya (fat tail) and Kuibyshev breeds.

Currently, the cattle purchase price is: for heifers - 170 rubles per $1 \mathrm{~kg}$ of live weight, cows - 120 rubles, calves - 140 rubles. The exception is a number of meat breeds: the price per $1 \mathrm{~kg}$ of live weight for livestock of Aberdeen - Angus and Hereford breeds is: for heifers - 190 rubles; cows - 150 rubles and calves - 160 rubles. [28]

From 2010-2013, livestock was acquired at the authorized capital expense. 9161 head cattle were purchased to the amount of 494.7 million rubles and 4471 head small cattle to the sum of 38.9 million rubles. From 2014 to 2016 animals were purchased as subsidies allocated from the regional budget. Budget financing for the farm animals purchase in 2014-2016 amounted to 366.0 million rubles, for which 4,579 head breeding stock cattles 
and 2245 head small cattle were bought. Additionally, at the own funds expense, 474 head cattle and 775 head small cattle were purchased in the amount of 31.9 million rubles. Since 2017, budget funds for the livestock purchase have not been allocated.

In 2017, in accordance with the "Conditions for concluding a commodity loan agreement to provide a breeding stock for farm animals of legal entities and individual entrepreneurs," livestock was transferred under commodity loan agreements for a period to 5 to 8 years, and in some cases up to 10 years. The annual interest rate value of the contract for a cattle commodity loan for the contract period (until September 30, 2017) amounted to $8.25 \%$ of the cattle value which was not repaid under the contract for cattle. Beginning with from October 1, 2017, the annual interest rate value makes up $5.0 \%$ of the cattle value and $3.5 \%$ of the small cattle value.

In total in 2017, cattle were transferred from purchases at their own expense and returned to the Samara region next recipients 2823 head, which is $18.3 \%$ less than in 2016 . 2910 head small cattle were delivered, which is $83.7 \%$ more.

For its activity period, the SUE «Veles» delivered cattle under commodity loan agreements to individual entrepreneurs and large agricultural producers such as «The South Volga Region» LLC of the Bolshechnerigovsky district, agricultural production cooperative «The Progress» of the Volzhsky distct, «The Samsonovskoye» LLC of the Isaklinsky District, and CJSC «Red Well» of the Isaklinsky district, «Agrocom» LLC, LLC named after Antonov, collective farm named after Kuibyshev and collective farm named after Kalyagin of the Kinelsky district, «Meat-agroprom» LLC of the Krasnoyarsk region, «Khryashchevka» LLC of the Stavropol district and many other farms in the region.

A positive example is the transfer of livestock under commodity loan agreements to the «Samsonovskoye» LLC of the Isaklinsky district (376 head), including 357 black-motley breed heifers and 19 Simmental heifers. The animals supply allowed the company to increase the livestock number as of 01.01.2019 to 604 animals, or 1.6 times, create an additional 27 jobs, reconstruct 3 cowsheds. 


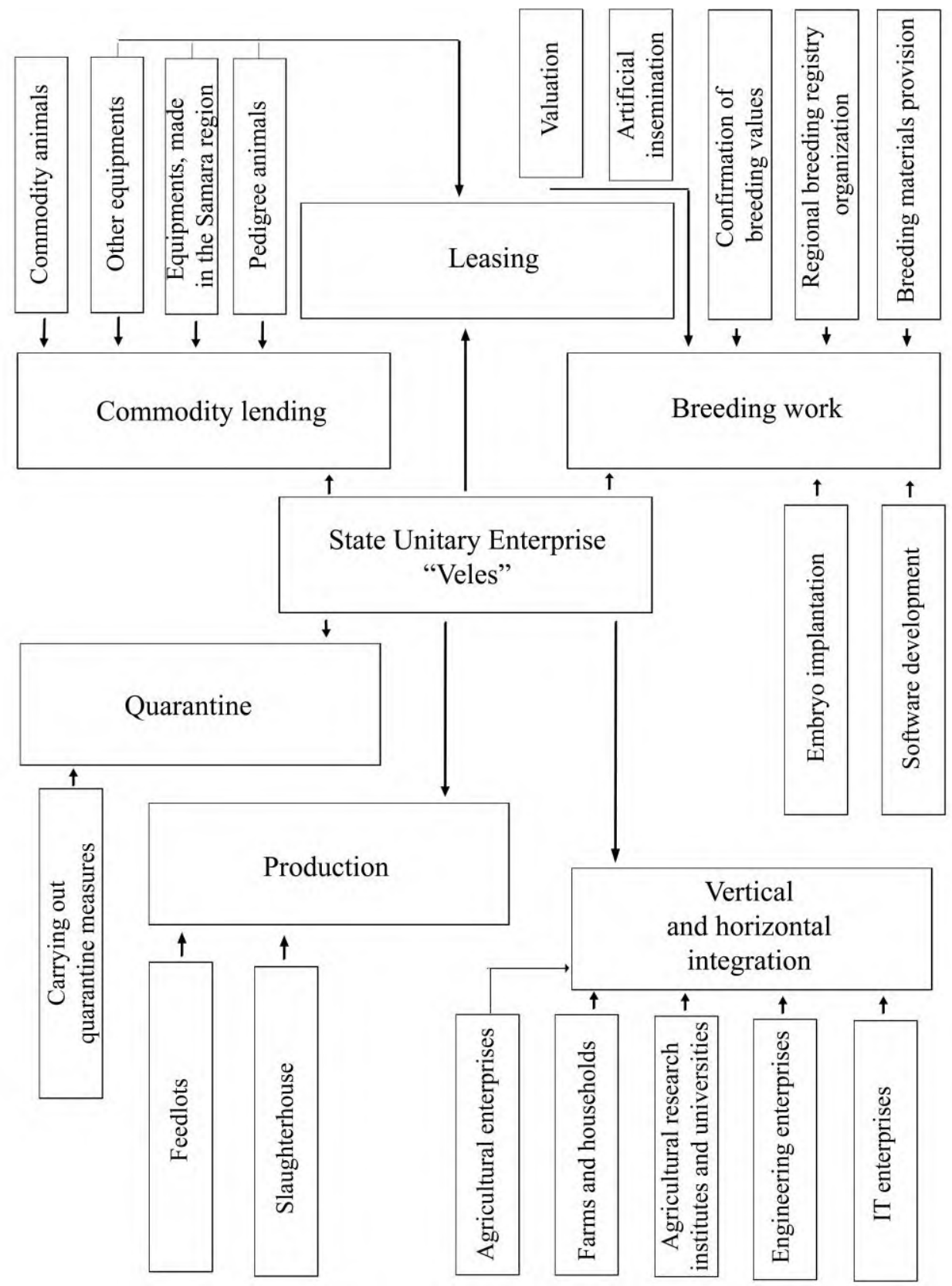

Fig. 2. Existing and promising areas of SUE «Veles» activity.

At present, it is planned to expand the enterprise scope, covering all new infrastructure areas (breeding, quarantine, etc.) (Fig. 2). In the short term, an increase in the share of pedigree cattle in the animals number transferred in the commodity credit form to the Samara region agricultural enterprises. Contacts accumulated in 2019, including foreign ones suggest the access possibility to the most modern world livestock breeding technologies and breeding material with high genetic potential. In order to expand the nomenclature and quality of livestock products produced in the region, it is necessary to envisage the expansion of the imported livestock breeds list due to highly specialized 
breeds (Jersey, Montbeliard, etc.) with the subsequent creation of pedigree breeds for these breeds in the region.

In the medium term, it is planned to expand the commodity lending functions through specialized equipment for livestock enterprises, mainly produced in the Samara region (Chelno-Vershinsky Mechanical Plant, etc.). In this area, close cooperation with the Samara Agricultural University and other universities of the region is expected to the modern technologies, equipment, IT-applications development to create a full cycle livestock production. The obtained developments are supposed to be provided to Samara agricultural producers either on the commodity loan or on lease terms.

\section{Conclusion}

Commodity lending is widespread, thanks to a variety of forms and conditions. Along with the traditional approach - the provision of goods on a paid, repayable, urgent basis, the type of commodity lending is widely used as a state support form, including in agricultural production. The most widespread such approach was in the United States, as part of the established Commodity Credit Corporation. It performs the functions wide variety within the state regulation framework. In the Russian Federation, the commodity lending practice is limited territorially (Tambov, Samara regions and a number of other regions) and functionally (support for the acquisition of commodity and pedigree animals for the herd replenishment). In the Samara region, the state support operator in the commodity lending form is the State Unitary Enterprise "Veles", which has been operating since 2010. Funds for the livestock purchase were contributed from the regional budget in the form of the enterprise authorized capital. Since 2016, the supply of a new livestock for agricultural enterprises in the region has been carried out at the expense of the SUE "Veles" own funds or by repaying a commodity loan. Currently, it is planned to an activity expand areas, including in the commodity lending framework. In the future, it is expected to create a full cycle livestock enterprises. Thanks to the SUE "Veles" activities from 2011 to 2016 it was possible to change the negative trend of livestock reduction in the region and ensure its growth.

\section{References}

1. M.S. Carolan, Sociologia Ruralis 53(4), 413-431 (2013) doi: 10.1111/soru.12020

2. S.B. Emery, Agriculture and Human Values 32(1), 47-61 (2014) doi: 10.1007/s10460014-9520-8

3. G.M. Robinson, Annual Review of Resource Economics 10, 133-160 (2018) doi: 10.1146/annurev-resource-100517-023303

4. K. Zhichkin, V. Nosov, L. Zhichkina, V. Zhenzebir, O. Sagina, IOP Conference Series: Earth and Environmental Science 421, 022066 (2020) doi: 10.1088/17551315/421/2/022066

5. D. van Dinh, Management Science Letters 10(5), 1001-1010 (2020) doi: 10.5267/j.msl.2019.11.010

6. S. Nazlioglu, U. Soytas, Energy Economics 34(4), 1098-1104 (2012) doi: 10.1016/j.eneco.2011.09.008

7. I. Bastiaens, E. Postnikov, Environmental Politics 26(5), 847-869 (2017) doi: 10.1080/09644016.2017.1338213

8. A.N. Rezitis, International Review of Applied Economics 29(3), 403-434 (2015) doi: 10.1080/02692171.2014.1001325 
9. M. Carolan, Sociologia Ruralis 57(2), 135-154 (2017) doi: 10.1111/soru.12120

10. G.K. MacDonald, K.A. Brauman, S. Sun, K.M. Carlson, E.S. Cassidy, J.S. Gerber, P.C. West, BioScience 65(3), 275-289 (2015) doi: 10.1093/biosci/biu225

11. J. French, Agribusiness 35(2), 219-233 (2019) doi: 10.1002/agr.21597

12. J.A. Picardy, S. Pietrosemoli, T.S. Griffin, C.J. Peters, Renewable Agriculture and Food Systems 34(1), 7-19 (2019) doi: 10.1017/S1742170517000230

13. E.V. Ball, S.L. Wang, R. Nehring, R. Mosheim, Applied Economic Perspectives and Policy 38(1), ppv031, 30-49 (2015) doi: 10.1093/aepp/ppv031

14. E. Ball, D. Schimmelpfennig, S.L. Wang, Applied Economic Perspectives and Policy 35(3), ppt014, 435-450 (2013) doi: 10.1093/aepp/ppt014

15. A.M. Johnson, M.D. Boehlje, M.A. Gunderson, Agricultural Finance Review 77 (1), 164-180 (2017) doi: 10.1108/AFR-06-2016-0057

16. A.L. Katchova, M.C. Ahearn, Agricultural Finance Review 77(1), 50-63 (2017) doi: 10.1108/AFR-03-2016-0021

17. H. Rusiana, B. Brewer, C. Escalante, Agricultural Finance Review 77(1), 153-163 (2017) doi: 10.1108/AFR-03-2016-0026

18. C.B. Dodson, B.L. Ahrendsen, Agricultural Finance Review 77(1), 78-94 (2017) doi: 10.1108/AFR-05-2016-0046

19. K.A. Zhichkin, V.V. Nosov, V.I. Andreev, O.K. Kotar, L.N. Zhichkina, IOP Conference Series: Earth and Environmental Science 341, 012005 (2019) doi:10.1088/1755-1315/341/1/012005

20. T. Serra, B.K. Goodwin, A.M. Featherstone, Journal of Econometrics 162(1), 18-24 (2011) doi: 10.1016/j.jeconom.2009.10.005

21. J.G. Peckham, J.D. Kropp, Agricultural and Resource Economics Review 41(2), 158 174 (2012) doi: 10.1017/S1068280500003324

22. A.M. Featherstone, Applied Economic Perspectives and Policy 40(1), 136-154 (2018) doi: 10.1093/aepp/ppy001

23. K. Zhichkin, V. Nosov, L. Zhichkina, IOP Conference Series: Earth and Environmental Science 403, 012073 (2019) doi:10.1088/1755-1315/403/1/012073

24. T.N. Medvedeva, I.A. Artamonova, I.N. Baturina, E.A. Farvazova, N. V. Roznina, E.G. Mukhina, IOP Conference Series: Earth and Environmental Science 341, 012010 (2019) doi:10.1088/1755-1315/341/1/012010

25. R.E. Carlin, T. Hellwig, Journal of Politics 82(2), 786-799 (2020) doi: 10.1086/706108

26. R. Lencucha, N.E. Pal, A. Appau, A.-M. Thow, J. Drope, Globalization and Health 16(1), 11 (2020) doi: 10.1186/s12992-020-0542-2

27. K. Zhichkin, V. Nosov, L. Zhichkina, IOP Conference Series: Earth and Environmental Science 337, 012009 (2019) doi:10.1088/1755-1315/337/1/012009

28. K. Zhichkin, V. Nosov, L. Zhichkina, V. Andreev, T. Mahanova, IOP Conference Series: Earth and Environmental Science 422, 012054 (2020) doi:10.1088/1755$1315 / 422 / 1 / 012054$ 